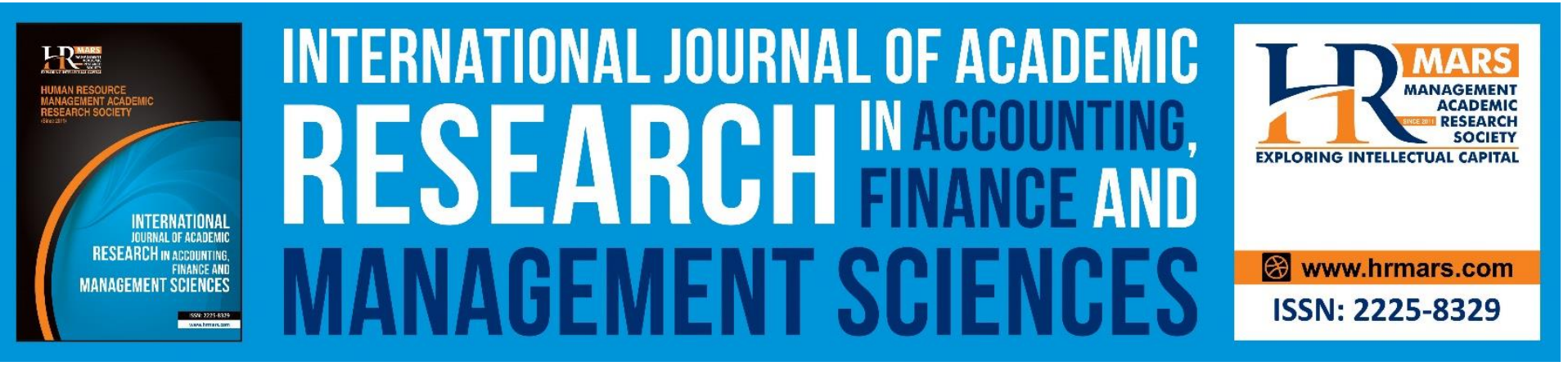

\title{
Virtual Teaching and Learning of Accounting in Technical Universities (TUs) in Ghana amid the COVID-19 Pandemic
}

\author{
Newman Amaning, Robertson Amoah, Peter Kwarteng, Enock Peprah
}

To Link this Article: http://dx.doi.org/10.6007/IJARAFMS/v10-i3/8063 DOI:10.6007/IJARAFMS/v10-i3/8063

Received: 03 July 2020, Revised: 28 July 2020, Accepted: 24 August 2020

Published Online: 27 September 2020

In-Text Citation: (Amaning, Amoah, Kwarteng, \& Peprah, 2020)

To Cite this Article: Amaning, N., Amoah, R., Kwarteng, P., \& Peprah, E. (2020). Virtual Teaching and Learning of Accounting in Technical Universities (TUs) in Ghana amid the COVID-19 pandemic. International Journal of Academic Research in Accounting, Finance and Management Sciences. 10(3), 400-417.

\section{Copyright: (C) 2020 The Author(s)}

Published by Human Resource Management Academic Research Society (www.hrmars.com)

This article is published under the Creative Commons Attribution (CC BY 4.0) license. Anyone may reproduce, distribute, translate and create derivative works of this article (for both commercial and non-commercial purposes), subject to full attribution to the original publication and authors. The full terms of this license may be seen

at: http://creativecommons.org/licences/by/4.0/legalcode

\section{Vol. 10, No. 3, 2020, Pg. 400 - 417}

Full Terms \& Conditions of access and use can be found at http://hrmars.com/index.php/pages/detail/publication-ethics 


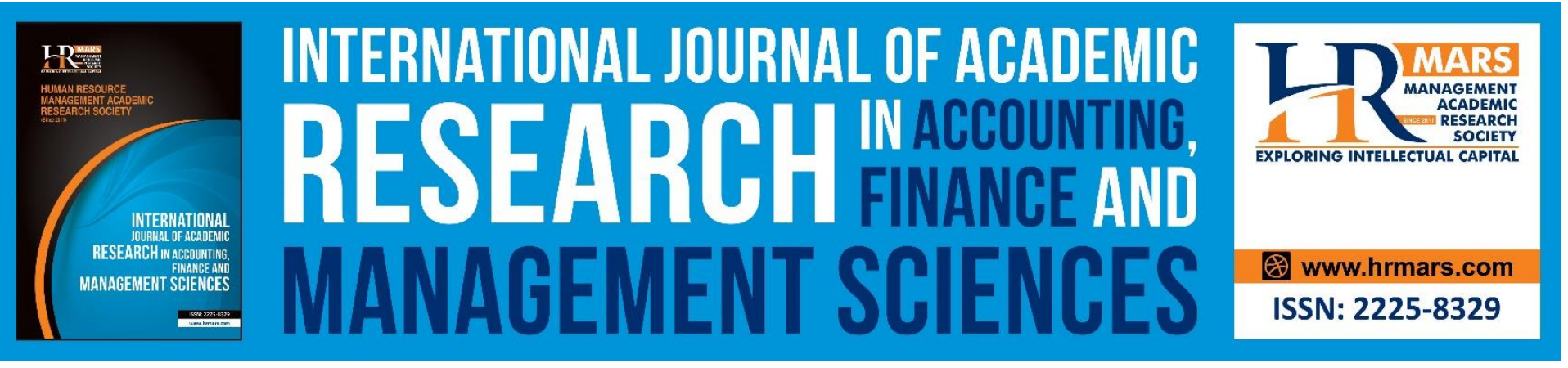

\title{
Virtual Teaching and Learning of Accounting in Technical Universities (TUs) in Ghana Amid the COVID-19 Pandemic
}

\author{
Newman Amaning ${ }^{1}$, Robertson Amoah ${ }^{2}$, Peter Kwarteng ${ }^{3}$, Enock \\ Peprah $^{4}$ \\ ${ }^{1-3}$ Faculty of Business and Management Studies, Sunyani Technical University, ${ }^{4}$ Accounts Unit, \\ Ghana Education Service, Oforikrom Senior School \\ Email: 1amaning_newman@stu.edu.gh, ${ }^{2}$ robekam@yahoo.com, ${ }^{3}$ kwartengpeter2006@yahoo.com, \\ ${ }^{4}$ enochpeprah2015@gmail.com
}

\begin{abstract}
The novel COVID-19 pandemic has affected every facet of life including education. Governments the world over adopted several measures and protocols, including shutting schools, introducing online teaching and learning on campuses as an alternative to the traditional face to face mode of delivery to minimise the impact of the pandemic. In this study, the effectiveness of the virtual teaching and learning of accounting adopted by authorities in Ghanaian TUs is explored. The Technology Acceptance Model (TAM) was used to formulate the hypotheses of this paper. The online survey was adopted to collect data from 315 respondents sampled purposively. In assessing both the measurement and structural models, Partial Least Square-Structural Equation Model (PLS-SEM) approach was adopted. The findings of the study prove that both mode of delivery and assessment, and period of delivery and assessment, have significant effects on the virtual teaching and learning of accounting in TUs in Ghana. This study is among the first papers to make significant attempts to explore the impact of the COVID-19 pandemic on teaching and learning in technical universities in Africa. This paper offers contributions to policymakers in tertiary institutions to have a better perspective of the effective virtual teaching and learning of accounting in TUs by both teachers and students. The researchers recommend that, the appropriate training opportunities for both learners and teachers on the virtual teaching and learning of accounting. This would go a long way to help students and teachers to discover the comprehensive and effective attributes of these virtual learning platforms to facilitate their effective usage.
\end{abstract}

Keywords: COVID-19 pandemic, Virtual Teaching and Learning of Accounting, Technical Universities, Partial Least Square-Structural Equation Model, Technology Acceptance Model 
INTERNATIONAL JOURNAL OF ACADEMIC RESEARCH IN ACCOUNTING, FINANCE AND MANAGEMENT SCIENCES

Vol. 10 , No. 3, 2020, E-ISSN: $2225-8329$ @ 2020 HRMARS

\section{Introduction}

The outbreak of the COVID-19 pandemic on public health scene globally has led to heightened concerns and uncertainties (Atuguba, 2020). The virus is akin to the" Spanish flu" of 1918-1919, "Asian flu" which occurred between 1957-1958, and "Hong Kong flu" of 1968-1969. These pandemics impacted human life and economic development (Longini, Halloran, Nizam, \& Yang, 2004). And according to the World Health Organisation, more than 20 million people died from the "Spanish flu" of 1918-1919 which has been recorded as the most catastrophic pandemic in human history (W.H.O., 2011b; Nickol \& Kindrachuk, 2019). The COVID-19 pandemics, just as all influenza pandemics are unpredictable. Nonetheless, they have a history of reoccurring approximately every $10-50$ years.

During the $21^{\text {st }}$ century, according to Rewar, Mirdha, and Rewar, (2015), the Influenza HINI 2009 virus, otherwise called A/2009/HINI, which affected the globe and killed more than 18,000 people, was the first pandemic influenza. More than 11,000 people died from Ebola and per the estimation of the World Bank, cost the world over \$2 billion (Maurice, 2016). Other viral diseases including the Zika virus of 2016 endangered the health of people in more than 30 countries (Troncoso 2016). Scientists and governments were depressed about the magnitude of the impact of the pandemics on global trade, economy and education.

The COVID-19 pandemic caused by Severe Acute Respiratory Syndrome coronavirus 2 (SARS-COV-2) has been tagged as a monster and compared to the economic sequence of World War Two (Wallace, Liebman, Chavez \& Wallace, 2020). The disease has had a devastating effect on health systems the world over and has impacted on every facet of human life to date (Sell \& Williams, 2020). The impact of the pandemic has been likened to those caused by smallpox, cholera, plague, dengue, AIDS, influenza, Severe Acute Respiratory Syndrome (SARS), West Nile disease and tuberculosis earlier in human history. Sohrabi et al (2020) outlined the scale of the pandemic with the World Health Organisation (WHO) declaring the COVID-19 as a global catastrophe on $30^{\text {th }}$ January, 2020. Gostin and Wiley (2020) posit that governments globally, as part of the measures to mitigate the impacts of the pandemic, have imposed border closures, restrictions on travels, shut down schools, quarantine of those infected with the disease and many others. This has resulted in causing fear of a looming economic disaster and downturn (Nicola et al., 2020).

Education, the world over is seen as the bedrock of national growth and development. Nevertheless, over the years, educational systems globally including Ghana's have been threatened by numerous challenges varying from the shut down of schools due to outbreak of diseases, unrests and riots by students or staff and political instability to modifications in school curricula. Presently, the global educational scene has not been spared by the impact of the COVID-19 pandemic. It has affected all levels of education; from pre-school to tertiary institutions. Consequently, countries numbering more than 100 hundred, including Ghana, in their response to the menace have enforced total shut down of schools. This shut down measure of educational facilities, according to UNESCO have affected close to 900 million learners globally (UNESCO, COVID-19 Educational Disruption and Response, 2020). Although the reason behind these shut downs is on a public health grounds to curb both the escalation of the virus within schools and the spread to other victims outside the institutions, they have resulted in profound universal socioeconomic implications. Some of the consequences include effect on nutrition due to the absence of free school meals given to students from low income homes in many countries such as Ghana, social seclusion, increased dropout rates with students less likely to come back when the shut downs are lifted, and an effect on childcare costs for families with younger children. 
INTERNATIONAL JOURNAL OF ACADEMIC RESEARCH IN ACCOUNTING, FINANCE AND MANAGEMENT SCIENCES

Vol. 10, No. 3, 2020, E-ISSN: 2225-8329 ๔ 2020 HRMARS

Recent studies such as Zhou et al. (2020); Cao et al. (2020) indicate that outbreak of pandemics on public health can have diverse psychological effects on learners, including anxiety, fear, worry and many others. According to Cornine et al. 2020, the college learners' anxiety emanates from the impact of the virus on their studies and future unemployment. According to Pandey et al., (2020); lack of interpersonal communications due to quarantine, can lead to anxiety disorders. The rising number of patients and suspected cases as well as the spread of the disease to other parts of the world, have elicited public concern about being inflicted in this pandemic, these have heightened anxieties of people the world over. Moreover, the shortage of masks and disinfectants, the overwhelming and sensational news headlines as well as fake news reports, have also contributed to anxiety and fear among learners. All these happenings consequently have had dire consequences on effective teaching and learning in schools.

The enforced shut down of schools, Lindzon (2020), argues, does not solely affect teachers, students, and families but have far reaching socioeconomic implications. According to previous studies such as Bear et al., (2020); Karp \& McGowan2020; and Ngumbi (2020), the closure of schools as a result of the COVID-19 pandemic have revealed diverse socioeconomic issues such as students' debt, digital learning, homelessness, food insecurity, health care, access to childcare, housing, internet and disability services respectfully. Jackson, Mangtani, Hawker, Olowokure, and Vynnycky (2014) posit that school closures due to the outbreak of communicable diseases earlier in human history resulted in varying degrees of effectiveness. For instance, during the heat of the "Spanish flu" of 1918-1919 pandemic in the United States, Barnum (2020) argues that shut down of schools and ban on public events achieved lower fatalities. In the opinion of Markel et al., (2007), states that implemented such interventions earlier recorded lower rates of deaths during the average duration of 4 weeks of such enforced measures. Shut downs of school carried out during the outbreak of the "Asian flu" of 19571958 , according to Chin, Foley, Doto and Gravelle (1960) resulted in the reduction in fatalities by $90 \%$. Wheeler, Erhart and Jehn (2010) also argue that up to $50 \%$ morbidity was achieved in mitigating influenza in US between 2004 - 2008 through school closure.

In addition, the existence of wide disparities in income levels among the population is also a factor. Students from higher income backgrounds can afford to have access to technology that can ensure that their education continues. However, the same cannot be said about students from poor homes as their economic status will impede their access to education during the pandemic. As a means to reducing such disparities in income-levels to ensure universal access to education, according to Nicola et al. (2020), in Dubai, for instance, close to 14,000 people "have backed a petition to decrease private school fees by $30 \%$ as parents struggle to source these funds amidst recent pay cuts reaching as high as $50 \%$, and high costs of living. Furthermore, parents are being asked to provide schools with confidential information such as bank statements and profit and loss company statements".

\section{Pedagogical Responses by Universities}

The response by countries to the effects of the pandemic on education have been wide and varied. For instance, in Australia, some universities such as Victoria University, 2020; Macquarie University,2020; and Monash University, 2020; put learning on hold temporary to design online learning whereas some universities including the University of Queensland, University of Technology Sydney, according to Crawford et al., (2020) are prepared to augment online teaching and learning with face to face learning, taking into account social distancing protocols. Some other universities including Australian National University, 2020 and University of Tasmania, 2020; have made rapid 
INTERNATIONAL JOURNAL OF ACADEMIC RESEARCH IN ACCOUNTING, FINANCE AND MANAGEMENT SCIENCES

Vol. 10, No. 3, 2020, E-ISSN: 2225-8329 @ 2020 HRMARS

advancement towards online learning without suspending face-to-face lectures. Some other universities such as University of Adelaide, University of Melbourne, and Deakin University, Worthington (2020); Ross (2020) argue, through compliance with the ban on social events of more than 500 people as at March 14, 2020, continue to have face-to-face interactions with learners amidst alternative teaching for large classes and seminars. Yet still, other universities have not made significant plans for domestic learners not requiring self-isolation (e.g. University of Western Australia, 2020). This evolution continued until the Australian government banned public indoor gatherings exceeding 100 people on 18 March (Bagshaw, 2020), and exclusions of all public gatherings exceeding two non-family/households announced on 24 March. This is likely to significantly affect those universities that did not move online immediately (Crawford et al. 2020). According to Perrota (2020), in China, the initial response to the pandemic was online delivery of training to students. Faculties immediately converted their curriculum to an online environment, taking into account websites and technology that could be assessed from China (Crawford et al. 2020). According to UNESCO (2020), countries such as South Korea, Iran and Italy equally changed their focus on educational operation. $\mathrm{Wu}(2020)$ posits that it the test of institutional capability which mainly focused on transitioning content to an online environment, and not primarily on online pedagogy. According to Zhong (2020), this demonstrated the impact of the pandemic on under resourced institutions and socially disadvantaged students to have access to technology and the internet to facilitate effective teaching and learning via the internet was limited. Several authors such a Houlden and Veletsianos, (2020) queried whether adequate preparations for tertiary educations were made for this digital era of teaching and learning.

In Africa, Egypt which is the most populous country in the Arab world with a total population above 90 million (World Population Review, 2020), reported 579 confirmed positive cases, with 36 deaths of the COVID-19 pandemic as at 29 March (WHO, 2020a). According to Ahram (2020); Reuters (2020a); Egypt just like to other Arab countries, has shut down schools, universities, and other educational institutions temporarily. The shut down has significantly affected hundreds of thousands of students. Prominent private universities, due to the shut down have made steps to offer teaching and learning online. For example, the British University in Cairo, offers teaching and learning via Moodle, Microsoft Class Notes as well as Microsoft Teams software (The British University in Cairo, 2020). American University in Cairo, on the other hand, has made steps to shift from face to face interaction between teachers and learners by embarking on online delivery using Blackboard, Moodle, email, and Zoom Cloud Meeting app (American University in Cairo, 2020). Admittedly, some of these gadgets were inuse prior to the pandemic, however, the devastating effects of the virus have accelerated measures to employ them. The large numbers of students admitted by most public universities such at the Alexandria University and the Cairo University, according to the Ministry of Higher Education and Scientific Research (2014), were some of the the challenges facing the rolling out e-learning. Other challenges to e-learning include the availability of the right hardware and software, internet connectivity, and storage capacity (Alexandria University, 2020). Nonetheless, Alexandria University, in the midst of these challenges, Crawford et al. (2020) argue, have opted for live and recorded sessions of lectures for students. The live situation of e-learning can be assessed if the infrastructure in terms of technology in public universities can facilitate online learning taking into the magnitude of traffic flow and connectivity.

In south Africa, by March 18, 2020, all universities and colleges have been ordered to shut down by the Ministry of Higher Education. All symposia and conferences were to be organised under 
INTERNATIONAL JOURNAL OF ACADEMIC RESEARCH IN ACCOUNTING, FINANCE AND

MANAGEMENT SCIENCES

Vol. 10, No. 3, 2020, E-ISSN: 2225-8329 ๔ 2020 HRMARS

restrictions Many universities including the University of Johannesburg, Fort Hare, Wits, and Cape Town put all forms of face to face lectures on hold (Crawfold et al., 2020). According to Sobuwa (2020), universities such as Rhodes, Witwatersrand, and Stellenbosch cancelled scheduled graduation ceremonies. Chothia (2020), reports that, universities were admonished to use the occasion to explore the possibility of virtual mode of teaching and learning.

In Nigeria, the most populous country on the African continent, all public and private schools in 10 states, according to Adnan (2020) were ordered to shut down in March 2020 to curtail the spread of the outbreak of the COVID-19 pandemic. Universities in the country were also ordered to close effective 23 March, 2020 as a "directive from the federal government to prevent the spread of the virus" (Adedigba, 2020). These directives disrupted teaching and learning in the country.

Ghana, which recorded its first case of the virus on 11 March, 2020, closed down schools including universities effective 16 March, 2020 following government directives to curtail the spread of the pandemic. This order was accepted by most stakeholders in the educational sector as a good measure to prevent the spread of the virus among students and others. Nonetheless, this directive has had effects on learners. According to Owusu-Fordjour et al. 2020, one of pioneer studies of the impact of the COVID-19 pandemic on learners in both the second cycle and tertiary institutions, revealed among others the following: (1) most educational institutions embraced e-learning through the internet as an alternative to face to face delivery, (2) the need of technological devices such as computers, tablets and mobile phones for teaching and learning through the internet, $(3)$ the lack of access to internet connectivity by most households in the country, (4) the suspension of the elearning platform introduced by the government, (5) the high cost of data, (6) lack of access to technological devices such as computers and smartphones by learners for effective learning (7) the absence of instructional materials for effective learning in most Ghanaian households, (8) the lack of the needed scaffolding for effective learning, (9) inadequate parental support to learners for effective learning on the virtual environment due to ignorance, absence from home etc. Their study which was to undertake a general investigation on the effect of the pandemic did not take into account the peculiarities of technical universities in Ghana and also the teaching of accounting which thrives well via a face-to-face interaction between lecturers and learners.

According to Mohmedbhai (2020), the consequences of the pandemic on higher education in Africa are devastating and include the following:

Inequities: The pandemic compelled African governments to shut down schools including universities to curtail the spread of the virus. Consequently, universities resorted to e-learning to facilitate teaching and learning. However, this measure has brought in its wake, the sharp digital divide that exists within the continent: between countries with better ICT facilities than others; between wellresourced universities than others in the same country, and between economically endowed learners who can afford these facilities and the rural poor in the same institution who can seldom afford these facilities should they be made available. Though it is a fact that the pandemic has given the leeway to all universities to enhance and optimise their ICT operations, most of these institutions are under resourced. Therefore, they do not have the capacity to roll out e-learning holistically.

Quality: It erroneous to comprehend that e-learning can be productive by simply uploading lecture notes (text or video) online. Nevertheless, that is the impression being created. Studies have revealed that scaffolding as a means of teaching is more productive than merely leaving students with lecture 
INTERNATIONAL JOURNAL OF ACADEMIC RESEARCH IN ACCOUNTING, FINANCE AND MANAGEMENT SCIENCES

Vol. 10, No. 3, 2020, E-ISSN: 2225-8329 @ 2020 HRMARS

notes to learn on their own. Because under this approach, unlike the unprepared e-learning delivery, the lecturer is pedagogically trained to facilitate effective teaching and learning. The ill-prepared elearning delivery will impact on the quality of the various programmes particularly practical-based programmes such as science and technology that require face-to-face demonstrations by experts.

Research: Efforts have been made over the years to enhance the quality of research on the continent which is known to be the lowest globally. Most of these studies are undertaken in collaboration with universities on the continent and foreign institutions and donors. As COVID-19 is affecting national economies, the success being made seem to be under threat as funding will be hit since most of these donors are likely to experience economic recession. Therefore, cannot afford to fund such researches.

Graduate unemployment: Graduate unemployment is a recent challenge continent-wide. And according to studies, the lack of "soft-skills" such as poor communication skills, the absence of personal initiative, inability to work with others in teams are the main attributing factors. And with the use of online learning in universities due to the pandemic, will definitely exacerbate the situation as students will work on their own. Unfortunately, employers could have stepped in to offer these needed soft skills are not spared from the impact of the pandemic. And so, will be compelled to lay off their staff. Hence will affect the chances of the university graduate to secure employment.

These happenings have increased our curiosity as academics about the implications of the virus in the lecture halls and campuses, and particularly the effects of the mode of delivery and assessment, and the period of delivery and assessment on the effective virtual teaching and learning of accounting in technical universities in Ghana which are mostly under resourced. It is against this background that this study seeks to explore effectiveness or otherwise of the adoption of virtual learning platforms on the teaching and learning of accounting in technical universities in Ghana in the midst of the novel COVID-19 pandemic. This study thus, seeks to achieve the following objectives:

- To verify if the mode of virtual delivery and assessment has influence on the perceived effective teaching and learning of accounting in TUs

- To verify if the period of virtual delivery and assessment has influence on the perceived effective teaching and learning of accounting in TUs

\section{Theoretical Framework and Research Hypotheses}

Several theories have been developed to study the acceptance innovative means of doing things, particularly in information system in which the virtual teaching and learning of accounting falls under. One of these is the Technology Acceptance Model (TAM). This model was coined by Davis in 1989 (Davis, 1989). This theory is an offshoot of the Theory of Reasoned Action (Fishbein \& Ajzen, 1975). This model is widely published by many scholars (see for example Almarabeh, 2014; Al-Emran, Elsherif, and Shaalan, 2016). In this study, TAM suggests that the behavioural intention of both the authorities of technical universities including lecturers and students to embrace virtual teaching and learning of accounting during the COVID-19 pandemic was influenced mainly by its perceived effectiveness. Perceived effectiveness in this context means adopting a particular system in which a person believes that it would enrich his or her job output. Thus, in the present study, TAM is used to measure the impact of various platforms accepted by technical universities to facilitate the effective virtual teaching and learning of accounting in the midst of the Novel COVID-19 pandemic that has led to governments the world over introducing social distancing measures, shutting down schools 
INTERNATIONAL JOURNAL OF ACADEMIC RESEARCH IN ACCOUNTING, FINANCE AND MANAGEMENT SCIENCES

Vol. 10, No. 3, 2020, E-ISSN: 2225-8329 @ 2020 HRMARS

including universities, embarking of lockdowns of cities and towns, etc. to check the spread and the effects of the disease. In the current study, TAM offers a solid background for the suitability of a virtual platform for teaching and learning of accounting in TUs. Added to this, TAM argues that technologically, when a new mode of teaching and learning is exposed to instructors and learners, it can have consequences. Based on that, the researchers tested the following hypotheses:

H1: Mode of virtual delivery and assessment influenced the perceived effective teaching and learning of accounting in TUs.

H2: Period of virtual delivery and assessment influenced the perceived effective teaching and learning of accounting in TUs.

\section{Research Methodology}

Context and subjects

This study was conducted in a cross section of TUs in Ghana. By March 14, 2020, the government of Ghana, like it's counterparts in most parts of the globe, introduced a lot of directives and protocols to minimise the devastating effects of the COVID-19 pandemic. These measures include social distancing directives, shutting down schools including universities, embarking of lockdowns of cities and towns, among others. Consequently, universities, including TUs adopted various virtual learning platforms in place of the traditional face to face mode to facilitate teaching and learning.

This study sample comprises of lecturers, HODs, and learners of TUs who were purposively selected. This technique gives the elements of the target population who have special knowledge of the subject the chance to be selected (Kuranchie, 2016). 283 valid answered responses were received out of a total of 315 administered questionnaires, which translates into a response rate of approximately $90 \%$.

\section{Survey instrument}

Due to the COVID-19 pandemic which prevented physical contacts with the respondents, an online questionnaire survey was sent to lecturers, Heads of Departmrnts (HoDs) and students within the Departments of Accounting of the selected TUs during the second semester of the 2019/2020 academic year purposely to collect data. The survey was made up of 4 sections. The foremost section was earmarked to collect demographic information of the respondents. The second section was devoted to collect data with respect to the mode of delivery and assessment of the virtual teaching and learning of accounting. The third section aimed at collecting data on the period of delivery and assessment of the virtual teaching and learning of accounting. The fourth and final section was dedicated to gathering data on effective virtual teaching and learning of accounting. The survey instrument was adapted from Al-Maroof and Al-Emran (2018) with further modification to fit the scope of this study.

\section{Data Analysis}

In this study, the researchers adopted the Partial Least Squares-Structural Equation Modelling (PLSSEM) employing SmartPLS 3 for the statistical analysis (Ringle, Wende and Becker, 2015). Moreover, because this research is an exploratory study, PLS-SEM is perceived as the appropriate tool for studies of this nature (Hair, Hult, Ringle and Sarstedt, 2016). With respect to the measurement model, PLSSEM recommended that the scholars should look at the outer loadings of the items and the average variance extracted (AVE) in order to establish the convergent validity. Added to these, Hair et al., (2016) suggested two measures for establishing a discriminant validity viz: cross loading and FornellLarcker criterion. Additionally, Henseler, Ringle and Sarstedt (2015) recommended examining the 
INTERNATIONAL JOURNAL OF ACADEMIC RESEARCH IN ACCOUNTING, FINANCE AND

MANAGEMENT SCIENCES

Vol. 10 , No. 3, 2020, E-ISSN: $2225-8329$ (c) 2020 HRMARS

Heterotrait-Monotrait as an additional criterion for analysing discriminant validity. With respect to the structural model, the path coefficients and the coefficient of determination $\left(R^{2}\right)$ were examined (Hair et al., 2016). Thus, the researchers made use of all the criteria mentioned above to assess the measurement and structural models.

\section{Results and Discussion}

\section{Descriptive Statistics}

The sample reveals the collected responses from the respondents which were 315 in all. However, the valid responses after sorting out missing items and outliers came to 283. Again Table 1 demonstrates the demographic information of the respondents. It can be observed that males form about $61 \%$ of the collected data while almost $39 \%$ are females. Besides, most of the respondents are within 20 -30 years, which constitute about $69 \%$ of the sample. In terms of the types of virtual learning platforms adopted, the Zoom Cloud Meeting app was the most popularly used, representing more than $72 \%$ of the sample. Other platforms such as Google Meet, YouTube, and WhatsApp, on the other hand, were moderately used.

\section{Assessing the measurement model}

In ascertaining the reliability of the various items, the factor loadings are to be measured. However, Hair et al. (2016) argue that a threshold value of $\geq 0.7$ for each variable is perceived as reliable. Added to this, Cronbach's Alpha and composite reliability values are to be $\geq 0.7$. Based on these arguments, both Mode of delivery and assessment, and Period of delivery and assessment had 8 items each but 5 were maintained for each of these independent variables, as the rest could not meet the benchmarks and were thus deleted (Figure 1 and Table 1 referred). Effective virtual teaching and learning, the dependent variable, had 12 items, and in line with the same arguments, only 5 were maintained. In measuring convergent validity, average variance extracted (AVE), which is a common measure of the grand mean figure of the squared loadings of the items is established. A threshold figure of $\geq 0.5$ of AVE implies that the model explains more than $50 \%$ of the variations of its items (Hair, Wollingsworth, Randolph and Chong, 2017). Inferring from Table 1, Cronbach's Alpha and composite reliability values are in excess of 0.7 and AVE figures more than 0.5 . Thus, the responses are both reliable and valid. In ascertaining if there exits collinearity problem or otherwise, the researchers examined both inner and outer Variance Inflation Factors (VIFs) (see Table 1 for results). Hair et al. (2017) conclude that the rule of thumb is VIF value should be lesser than 5. Inferring from Table 1, of the values of the outer VIF are lesser than the threshold. We, therefore, establish that the presence of collinearity problem(s) is not seen in this model. 
INTERNATIONAL JOURNAL OF ACADEMIC RESEARCH IN ACCOUNTING, FINANCE AND MANAGEMENT SCIENCES

Vol. 10, No. 3, 2020, E-ISSN: 2225-8329 @ 2020 HRMARS

Table 1: Measurement Model Results

\begin{tabular}{|c|c|c|c|c|c|c|c|}
\hline Constructs & Items & Loadings & CA & CR & AVE & $\begin{array}{l}\text { VIF } \\
\text { (Inner) }\end{array}$ & $\begin{array}{l}\text { VIF } \\
\text { (Outer) }\end{array}$ \\
\hline Effective & E1 & 0.765 & & & & & 2.934 \\
\hline virtual & E2 & 0.778 & & & & & 3.398 \\
\hline teaching & E7 & 0.819 & 0.859 & 0.899 & 0.636 & & 2.382 \\
\hline and & E8 & 0.822 & & & & & 3.008 \\
\hline learning & E9 & 0.802 & & & & & 2.913 \\
\hline Mode of & MDA1 & 0.936 & & & & & 4.657 \\
\hline delivery & MDA2 & 0.923 & & & & & 4.889 \\
\hline and & MDA4 & 0.915 & 0.943 & 0.957 & 0.815 & 2.009 & 4.192 \\
\hline assessmen & MDA5 & 0.900 & & & & & 3.742 \\
\hline $\mathrm{t}$ & MDA8 & 0.837 & & & & & 2.212 \\
\hline Period of & P1 & 0.744 & & & & & 1.726 \\
\hline delivery & $\mathrm{P} 2$ & 0.764 & & & & & 1.866 \\
\hline and & P3 & 0.866 & 0.896 & 0.916 & 0.688 & 2.009 & 2.737 \\
\hline assessmen & P4 & 0.898 & & & & & 3.478 \\
\hline $\mathrm{t}$ & P5 & 0.863 & & & & & 2.704 \\
\hline
\end{tabular}

Note: $C A=$ Cronbach's Alpha; $C R=$ Composite Reliability; AVE= Average Variance Extracted; VIF= Variance inflation factor.

Besides, there is a strong positive correlation existing between the dependent variable (i.e. effective virtual teaching and learning) and the independent variables (i.e. mode of delivery and assessment, and period of delivery and assessment). Also, despite the fact that there is a strong positive correlation ( $\cong 71 \%$ ) existing between mode of delivery and assessment, and period of delivery and assessment, it does not lead to multicollinearity challenges in the model (see Table 2).

Table 2: Correlation Matrix of Latent Variables

\begin{tabular}{llll}
\hline Variable & $\mathbf{E}$ & MDA & $\mathbf{P}$ \\
\hline $\mathrm{E}$ & 1.000 & & \\
$\mathrm{MDA}$ & 0.81 & 1.000 & \\
$\mathrm{P}$ & 0.706 & 0.709 & 1.000 \\
\hline
\end{tabular}

Note: $E=$ Effective virtual teaching and learning; $M D A=$ Mode of Delivery and Assessment; $P=$ Period of Delivery and Assessment

In achieving discriminant validity, the researchers analysed the Fornell-Larckel criterion, HeterotraitMonotrait Ratio, and cross loadings. With respect to the Fornell-Larckel, the square root of AVE (diagonal figure) for each variable should be more than the correlation of the latent variables. In this study, this has been established (see Table 2 and Table 3). In terms of the Heterotrait-Monotrait ratio (HTMT), a figure smaller than 0.90 is acceptable (Henseler et al., 2015). Inferring from Table 5, this 
INTERNATIONAL JOURNAL OF ACADEMIC RESEARCH IN ACCOUNTING, FINANCE AND

MANAGEMENT SCIENCES

Vol. 10, No. 3, 2020, E-ISSN: 2225-8329 @ 2020 HRMARS

has been met. Regarding the cross loadings' threshold, this too has been met (see Table 6). Accordingly, the discriminant validity of the study has been met.

Table 3: Fornell-Larckel

\begin{tabular}{llll}
\hline Variable & E & MDA & P \\
\hline E & 0.797 & & \\
MDA & 0.810 & 0.903 & \\
$\mathrm{P}$ & 0.706 & 0.709 & 0.829 \\
\hline
\end{tabular}

Note: E=Effective virtual teaching and learning; $M D A=$ Mode of Delivery and Assessment; $P=$ Period of Delivery and Assessment

Table 4: Heterotrait-Monotrait Ratio (HTMT)

\begin{tabular}{llll}
\hline Variable & E & MDA & P \\
\hline $\mathrm{E}$ & & & \\
$\mathrm{MDA}$ & 0.875 & & \\
$\mathrm{P}$ & 0.783 & 0.763 & \\
\hline
\end{tabular}

Note: $E=$ Effective virtual teaching and learning; $M D A=$ Mode of Delivery and Assessment; $P=$ Period of Delivery and Assessment

Table 5: Cross Loadings Results

\begin{tabular}{llll}
\hline & $E$ & MDA & $P$ \\
\hline E1 & 0.765 & 0.529 & 0.462 \\
E2 & 0.778 & 0.514 & 0.470 \\
E7 & 0.819 & 0.619 & 0.556 \\
E8 & 0.822 & 0.765 & 0.628 \\
E9 & 0.802 & 0.734 & 0.648 \\
MDA1 & 0.737 & 0.936 & 0.615 \\
MDA2 & 0.731 & 0.693 & 0.659 \\
MDA4 & 0.692 & 0.915 & 0.610 \\
MDA5 & 0.900 & 0.584 \\
MDA8 & 0.789 & 0.837 & 0.714 \\
P1 & 0.789 & 0.474 & 0.744 \\
P2 & 0.491 & 0.495 & 0.764 \\
P3 & 0.489 & 0.607 & 0.866 \\
P4 & 0.582 & 0.687 & 0.898 \\
P5 & 0.702 & 0.640 & 0.863 \\
\hline & 0.628 & & \\
\hline
\end{tabular}




\section{Structural Model Assessment}

The explanatory ability of the model is established by measuring the variation amount in the proxies of the dependent variable within the model. The $\mathrm{R}^{2}$ and the path coefficients, according to Hair et al., (2016) are the critical metrics in examining the model (see figure 1 and Table 7). it can be observed from Table 7 that $69.2 \%$. of the variance for the effective virtual teaching and learning of accounting in TUs is explained by the independent variables, (i.e. mode of delivery and assessment, and period of delivery and assessment). The model is thus, very fit. Also, it can be observed that all the hypotheses are supported. This further shows the significance of all the paths between the independent and dependent variables. $\mathrm{H} 1(\beta=0.622, \mathrm{P}<0.01)$ shows the path between the mode of delivery and assessment, and effective virtual teaching and learning of accounting. This phenomenon explains that mode of delivery and assessment enhances the effective virtual teaching and learning of accounting. $\mathrm{H} 2(\beta=0.265, \mathrm{P}<0.01)$ describes the path between the period of delivery and assessment, and effective virtual teaching and learning of accounting; representing that the period of delivery and assessment affects the effective virtual teaching and learning of accounting.

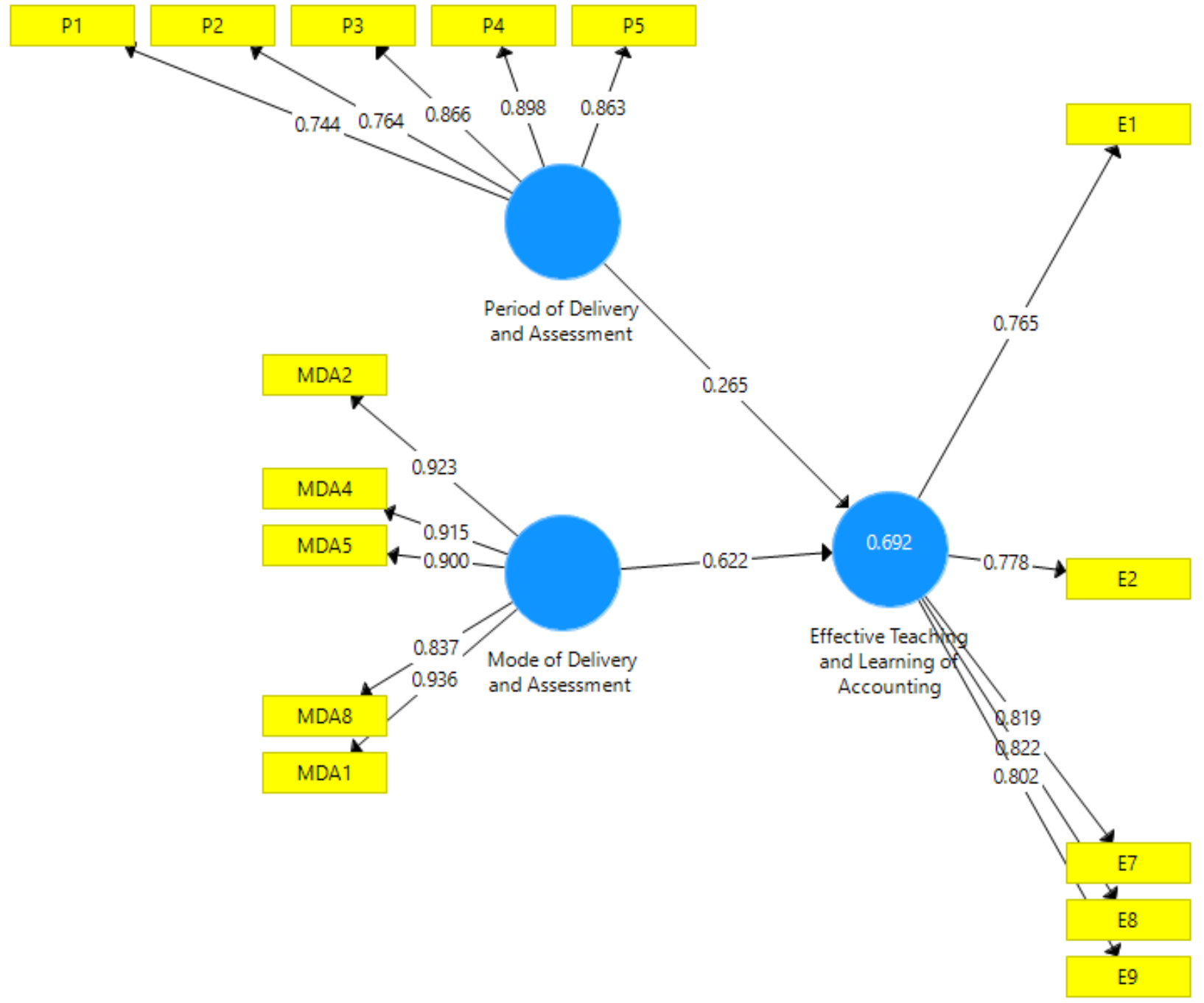

Figure 1: Results of Path Analysis 
INTERNATIONAL JOURNAL OF ACADEMIC RESEARCH IN ACCOUNTING, FINANCE AND MANAGEMENT SCIENCES

Vol. 10 , No. 3, 2020, E-ISSN: 2225-8329 @ 2020 HRMARS

Table 6: Hypothesis Tests and Model Fitness Results

\begin{tabular}{lllll}
\hline Hypothesis & Path & Path Coefficient ( $\boldsymbol{\beta})$ & P-value & Remarks \\
\hline H1 & $\mathrm{MDA} \rightarrow E$ & 0.622 & 0.000 & Supported \\
H2 & $\mathrm{P} \rightarrow E$ & 0.265 & 0.001 & Supported \\
Model Fit & & & & \\
R2 & 0.692 & & & \\
R2-Adjusted & 0.687 & & & \\
\hline
\end{tabular}

The study results suggest that both mode of delivery and assessment, and period of delivery and assessment significantly impact on the effectiveness of the virtual teaching and learning of accounting at TUs. This conclusion is inconsistent with the argument of Mohmedbhai (2020). This study's outcomes have consequences on the adoption of the pedagogical tools in the teaching and learning process of accounting amid the COVID-19 pandemic. This position is partly consistent with the argument of Jackson et al. (2014). Meanwhile, the arguments of scholars including Cornine (2020), and Pandey et al. (2020), about the health and psychological effects of school closure such as fear and anxiety are at variant with the outcome of this study. Therefore, this paper establishes that both the mode of delivery and assessment, and period of delivery and assessment have positive influence on the effectiveness of the virtual teaching and learning of accounting at TUs. We, thus recommend that policymakers in tertiary institutions should take these results in consideration in their future attempts to promote virtual teaching and learning.

\section{Conclusion and Suggestions for Future Studies}

This study explores the mode of delivery and assessment, and period of delivery and assessment on the effective virtual teaching and learning of accounting in TUs in Ghana amid the COVID-19 pandemic by adopting TAM. Measurement and structural models were examined using the PLS-SEM approach. The results of the study reveal the significance of the mode of delivery and assessment, and period of delivery and assessment towards effective teaching and learning of accounting.

In our opinion, the assessment benchmarks put forward and contrasted in this paper elucidate the effective virtual teaching and learning of accounting through a suitable mode and period of delivery and assessment in tertiary institutions. Consequently, in line with this study's outcomes, policymakers of educational institutions are asked to appreciate the effects of the independent variables on effective virtual teaching and learning of accounting in TUs and integrate them into the adoption of the various virtual platforms. To further enhance the effectiveness of the various virtual platforms adopted, we suggest that the authorities in the various TUs should provide the appropriate training opportunities for both learners and teachers. This would go a long way to help students and teachers to discover the comprehensive and effective attributes of these virtual learning platforms to facilitate their effective usage.

Undeniably, every study, including this paper, has its weaknesses. The weaknesses of this study include: One, the factors of the adopted model, TAM, were not fully utilised. Future studies should address that and make allowance for the necessary modifications. Two, the study was only conducted on a cross section of TUs in Ghana. Hence the outcome could be generalised to all tertiary institutions in Ghana. Thus, future studies are required to address this constraint. Again, this study was only 
INTERNATIONAL JOURNAL OF ACADEMIC RESEARCH IN ACCOUNTING, FINANCE AND

MANAGEMENT SCIENCES

Vol. 10, No. 3, 2020, E-ISSN: 2225-8329 @ 2020 HRMARS

restricted the effective virtual teaching and learning of accounting in TUs in Ghana. Future studies are expected to replicate it on other disciplines for the outcomes to be compared.

In line with the applications of the principles TAM theory to this paper, the researchers have made invaluable contribution to virtual teaching and learning of accounting in TUs. This study has also shed light on how improvement can be made on some aspects of the TAM theory due to technological advancement in the virtual learning landscape. The TAM, thus needs to be revisited to reflect the paradigm toward an aggressive virtual teaching and learning in the world today. Nevertheless, this study is among the first papers to make significant attempts to explore the impact of the COVID-19 pandemic on teaching and learning in technical universities in Africa using TAM.

\section{References}

Adedigba, A. (2020). Coronavirus: NUC announces closure of Nigerian universities, Premium Times.https://www.premiumtimesng.com/news/headlines/382880-coronavirusnuc-announces-closure-of-nigerianuniversities.html

Adnan, A. (2020). Nigeria ramps up response efforts to smash coronavirus, Anadolu Agency.https://www.aa.com.tr/en/africa/nigeria-ramps-up-response-efforts-tosmashcoronavirus/1771922

Ahram Online. (2020). Egypt Closes Schools and Universities for Two Weeks over Coronavirus Concern. Ahram Online. http://english.ahram.org.eg News

Content1/64/365268/Egypt/Politics/Egypt-closesschools-and-universities-for-twoweek.aspx

Alexandria University. (2020). LiveBroadcast of Student Classes Start. https://www.alexu.edu.eg/index.php/ar/2018- 04-02-10-35-29/5684

Al-Maroof, R. A. S., \& Al-Emran, M. (2018). Students acceptance of Google classroom: An exploratory study using PLS-SEM approach. International Journal of Emerging Technologies in Learning (iJET), 13(06), 112-123.

Almarabeh, T. (2014). Students' Perceptions of E-Learning at the University of Jordan. International Journal of Emerging Technologies in Learning, 9(3).

Al-Emran, M., Elsherif, H. M., \& Shaalan, K. (2016). Investigating attitudes towards the use of mobile learning in higher education. Computers in Human behavior, 56, 93-102.

American University in Cairo. (2020). AUC Next Steps on COVID-19: Online Instruction to Begin. https://www.aucegypt.edu/news/auc-next-steps-COVID-19-onlineinstructionbegin

Ataguba, J. E. (2020). COVID-19 pandemic, a war to be won: understanding its economic implications for Africa. Journal of Applied Health Economics and Health Policy, 18, 325-328. Springer, Switzerland

Australian National University. (2020). Information for students - 17 March 2020. https://www.anu.edu.au/news/ all-news/information-for-students-0

Bagshaw, E. (2020). Travel warning raised, indoor mass gatherings over 100 people prohibited. Sydney Morning Herald. https://www.smh.com.au/politics/federal/ travelwarning-raised-indoor-mass-gatherings-over-100- people-prohibited-20200318p54b85.html 
INTERNATIONAL JOURNAL OF ACADEMIC RESEARCH IN ACCOUNTING, FINANCE AND

MANAGEMENT SCIENCES

Vol. 10, No. 3, 2020, E-ISSN: 2225-8329 @ 2020 HRMARS

Bao, Y., Sun, Y., Meng, S., Shi, J., Lu, L. (2020). 2019-nCoV epidemic: address mental health care to empower society. Lancet. https://doi.org/10.1016/S0140-6736(20)30309-3. Online First.

Barnum, M. (2020). Chalkbeat. Retrieved from Chalkbeat Web site: http//www.chalkbeat.com

Bear, L., James, D., Simpson, N., Alexander, E., Bhogal, J. K., Bowers, R., \& Long, N. J. (2020). A right to care: the social foundations of recovery from Covid-19.

Cao, W., Fang, Z., Hou, G., Han, M., Xu, X., Dong, J., \& Zheng, J. (2020). The psychological impact of the COVID-19 epidemic on college students in China. Psychiatry research, 112934.

Chin, T., Foley, J., Doto, L., Gravelle, R., \& Weston, J. (1960). Morbidity and mortality characteristics of Asian strain influenza. Public Health Reports, 75(2), 148-158.

Chothia, A. (2020). Coronavirus outbreak closes all South African universities, colleges. The South African.

Cornine, A. (2020). Reducing nursing student anxiety in the clinical setting: An integrative review. Nursing education perspectives, 41(4), 229-234.

Crawford, J., Butler-Henderson, K., Rudolph, J., Malkawi, B., Glowatz, M., Burton, R., \& Lam, S. (2020). COVID-19: 20 countries' higher education intra-period digital pedagogy responses. Journal of Applied Learning \& Teaching, 3(1), 1-20.

Davis, F. D. (1989). Perceived usefulness, perceived ease of use, and user acceptance of information technology. MIS quarterly, 319-340.

Fishbein, M., \& Ajzen, I. (1977). Belief, attitude, intention, and behavior: An introduction to theory and research.

Gostin, L. O., \& Wiley, L. F. (2020). Governmental public health powers during the COVID-19 pandemic: Stay-at-home orders, business closures, and travel restrictions. JAMA.

Hair, J., Hollingsworth, C. L., Randolph, A. B., \& Chong, A. Y. L. (2017). An updated and expanded assessment of PLS-SEM in information systems research. Industrial Management \& Data Systems.

Hair, J. J. F., Hult, G. T. M., Ringle, C., \& Sarstedt, M. (2016). A primer on partial least squares structural equation modeling (PLS-SEM). Sage publications.

Henseler, J., Ringle, C. M., \& Sarstedt, M. (2015). A new criterion for assessing discriminant validity in variance-based structural equation modeling. Journal of the academy of marketing science, 43(1), 115-135.

Houlden, S., \& Veletsianos, G. (2020). Coronavirus pushes universities to switch to online classes - but are they ready. The Conservation.

Jackson, C., Mangtani, P., Hawker, J., Olowokure, B., \& Vynnycky, E. (2014). The effects of school closures on influenza outbreaks and pandemics: systematic review of simulation studies. Plos one, 9(5), e97297.

Karp, P., \& McGowan, M. (2020). Clear as mud: schools ask for online learning help as coronavirus policy confusion persists. The Guardian, 261-307.

Kuranchie, A. (2016). Research Made Easy. (2nd ed.). Kumasi: Book Worm Publications

Lindzon, J. (2020). School closures are starting, and they'll have far-reaching economic impacts. Fast Company, 11-13.

Longini, J. I. M., Halloran, M. E., Nizam, A., \& Yang, Y. (2004). Containing pandemic influenza with antiviral agents. American journal of epidemiology, 159(7), 623-633. 
INTERNATIONAL JOURNAL OF ACADEMIC RESEARCH IN ACCOUNTING, FINANCE AND

MANAGEMENT SCIENCES

Vol. 10, No. 3, 2020, E-ISSN: 2225-8329 @ 2020 HRMARS

Macquarie University. (2020). Coronavirus (COVID-19) infection: latest information.

https://www.mq.edu.au/about/ coronavirus-faqs

Markel, H., Lipman, H. B., Navarro, J. A., Sloan, A., Michalsen, J. R., Stern, A. M., \& Cetron, M. S.

(2007). Nonpharmaceutical Interventions Implemented by US Cities

Maurice, J. (2016). Cost of protection against pandemics is small. The Lancet, 387 - 412.

Mohmedbhai, G. (2020, April 9). COVID-19: What consequences for higher education? World

University News: Africa Edition. Retrieved from https://www.universityworldnews.com/

Monash University. (2020). COVID-19 - fact sheet. Monash University.

https://www.monash.edu/news/COVID-19-factshee

Ngumbi, E. (2020). Coronavirus closings: Are colleges helping their foreign, homeless and poor students? USA Today, 11-14

Nickol, M. E., \& Kindrachuk, J. (2019). A year of terror and a century of reflection: perspectives on the great influenza pandemic of 1918-1919. BMC infectious diseases, 19(1), 117.

Nicola, M., Alsafi, Z., Sohrabi, C., Kerwan, A., Al-Jabir, A., losifidis, C., \& Agha, R. (2020). The socio-economic implications of the coronavirus and covid-19 pandemic: $A$ review. International Journal of Surgery.

Owusu-Fordjour, C., Koomson, C. K., \& Hanson, D. (2020). THE IMPACT OF COVID-19 ONLEARNINGTHE PERSPECTIVE OF THE GHANAIAN STUDENT. European Journal of Education Studies. Pandey, D., Bansal, S., Goyal, S., Garg, A., Sethi, N., Pothiyill, D. I., ... \& Sethi, R. (2020). Psychological impact of mass quarantine on population during pandemics -The COVID- 19 Lock-Down (COLD) study. Plos one, 15(10), e0240501.

Perrotta, C. (2020). Coronavirus quarantine could spark an online learning boom. The Conversation. https:// theconversation.com/coronavirus-quarantine-could-sparkan-onlinelearning-boom-132180

Reuters. (2020). Egypt shuts schools, universities for two weeks as virus cases increase. Free Malaysia Today. https://www.reuters.com/article/us-health- coronavirusegypt/egyptshuts-schools-universities-for-two-weeks-asvirus-cases-increase- idUSKBN2110SH

Rewar, S., Mirdha, D., \& Rewar, P. (2015). Treatment and prevention of pandemic H1N1 influenza. Annals of global health, 81(5), 645-653.

Ringle, C. M., Wende, S., \& Becker, J. M. (2015). SmartPLS 3. Boenningstedt: SmartPLS GmbH.

Ross, J. (2020). Classes suspended at some Australian universities. Times Higher Education. https://www. timeshighereducation.com/news/classes-suspended- $\quad$ someaustralianuniversities

Sell, S. K., \& Williams, O. D. (2020). Health under capitalism: a global political economy of structural pathogenesis. Review of International Political Economy, 27(1), 1-25.

Sobuwa, Y. (2020). Universities cancelling in-person classes due to coronavirus. Sowetan Live. https://www.sowetanlive. co.za/news/south-africa/2020-03-16-universitiescancelling-inperson-classes-due-to-coronavirus/

Sohrabi, C., Alsafi, Z., O’Neill, N., Khan, M., Kerwan, A., Al-Jabir, A., ... \& Agha, R. (2020). World Health Organization declares global emergency: A review of the 2019 novel coronavirus (COVID-19). International Journal of Surgery.

The British University in Cairo. (2020). Contingency plan for learning and teaching. https://www.bue.edu.eg/ teach-and-learn-remotely/ 
INTERNATIONAL JOURNAL OF ACADEMIC RESEARCH IN ACCOUNTING, FINANCE AND

MANAGEMENT SCIENCES

Vol. 10, No. 3, 2020, E-ISSN: 2225-8329 @ 2020 HRMARS

Troncoso, A. (2016). Zika threatens to become a huge worldwide pandemic. Asian Pacific Journal of Tropical Biomedicine, 6(6), 520-527.

UNESCO. (2020). COVID-19 Educational disruption and response. Geneva: UNESCO https://en.unesco.org/themes/educationemergencies/coronavirus-school-closures

University of Adelaide. (2020). Newsroom: Novel coronavirus (COVID-19).

University of Tasmania. (2020). COVID-19 updates. https:// www.utas.edu.au/alerts/coronavirus-update

University of Western Australia. (2020). COVID-19 FAQ. https://www.web.uwa.edu.au/novelcoronavirus\#new_div_3446928

Victoria University. (2020). Coronavirus (COVID-19). https://www.vu.edu.au/about-vu/news-events/news/vus-responseto-the-coronavirusCOVID-19

Wallace, R., Liebman, A., Chavez, L. F., \& Wallace, R. (2020). COVID-19 and Circuits of Capital. Monthly Review, 72.

Wheeler, C., Erhart, L., \& Jehn, M. (2010). Effect of school closure on the incidence of influenza among school -age children in Arizona. Public Health Reports, 125(6), 851- 859

W.H.O. (2011b). Comparative Analysis of National Pandemic Influenza Preparedness Plan. Geneva-Switzerland: WHO.

World Health Organization. (2020a). Coronavirus disease (COVID-2019) situation reports. Situation report - 64 (29 March 2020). https://www.who.int/emergencies/diseases/ novelcoronavirus-2019/situation-reports

World Population Review. (2020). Arab countries 2020. https:// worldpopulationreview.com/countries/arab-countries

Worthington, B. (2020). Gatherings of more than 500 people to be cancelled, Australians urged not to travel overseas amid coronavirus fears. Australian Broadcasting Commission. https://www.abc.net.au/news/2020-03-13/ coronavirus-scott-morrison- coag-premierscancellingevents/12053382https://www.adelaide.edu.au/newsroom/ COVID-19

Wu, Z. (2020). How a top Chinese university is responding to coronavirus. https://www.weforum.org/agenda/2020/03/ coronavirus-china-the-challenges-of-onlinelearning-foruniversities/

Zhong, R. (2020). The coronavirus exposes education's digital divide. The New York Times. https:// www.nytimes.com/2020/03/17/technology/china-schoolscoronavirus.html

Zhou, S. J., Zhang, L. G., Wang, L. L., Guo, Z. C., Wang, J. Q., Chen, J. C., \& Chen, J. X. (2020). Prevalence and socio-demographic correlates of psychological health problems in Chinese adolescents during the outbreak of COVID-19. European Child \& Adolescent Psychiatry, 1-10. 


\section{Item}

1. Virtual teaching of accounting enhances my efficiency (E1)

2. Virtual teaching and learning augments the government's efforts of minimising the spread of the virus (E2)

3. Virtual teaching and learning is convenient and user friendly (E7)

4. Virtual teaching and learning of accounting is time saving and productive (E8)

5. Virtual teaching and learning minimises all psychological and health effects of the pandemic including anxiety, fears, etc. (E9)

6. There are recorded and live sessions of lectures (MDA1)

7. The mode of delivery on the virtual platforms are very interactive (MDA2)

8. Virtual teaching and learning is not boring but rather full of fun (MDA4)

9. Assignments and quizzes conducted virtually are not compromised (MDA5)

10. Skilled and experienced teachers and technicians handle the virtual learning platform(s) (MDA8)

11. Time tables are prepared for virtual lectures and quizzes (P1)

12. Lectures and quizzes are always held on schedule (P2)

13. Adherence to periodic lectures and conduct of quizzes inculcate the culture of discipline into students (P3)

14. Students can submit their assignments at any time (P4)

15. Teachers and technicians are available at any time to offer the needed assistance to learners (P5) 